\title{
ANALISIS KEMAMPUAN PEMECAHAN MASALAH DITINJAU DARI MOTIVASI BELAJAR MATEMATIKA SISWA
}

\author{
${ }^{1}$ Wangsit Rigusti, ${ }^{2}$ Heni Pujiastuti \\ ${ }^{1,2}$ Universitas Sultan Ageng Tirtayasa, Jl. Raya Jakarta KM.4, Panancangan, Kec. Serang, Kota Serang, Banten \\ 42124, (0254) 280330, Indonesia \\ e-mail: wangsitfrima2@gmail.com
}

\begin{abstract}
Abstrak
Penelitian ini bertujuan untuk mendeskripsikan kemampuan pemecahan masalah ditinjau dari motivasi belajar matematika siswa. Penelitian ini merupakan jenis penelitian deskriptif kuantitatif. Pokok bahasan dalam penelitian ini adalah statistika. Subjek dalam penelitian ini adalah siswa kelas XII IPS 1 SMA Negeri 17 Pandeglang tahun ajaran 2019/2020 yang berjumlah 32 siswa. Instrumen pengumpulan data yang digunakan antara lain soal test akhir untuk melihat kemampuan pemecahan masalah siswa dan lembar angket motivasi belajar siswa. Teknik analisis data dalam penelitian ini menggunakan persentase skor dan anova dua jalur. kemampuan pemecahan masalah dan motivasi belajar matematika siswa dilihat dari kategori tinggi, sedang, dan rendah. Berdasarkan hasil pengolahan data, bahwa sebaran motivasi belajar tinggi $25 \%$ siswa, motivasi belajar sedang $47 \%$ siswa, dan motivasi rendah $28 \%$ siswa. Dengan skor ideal 100, diperoleh rata- rata kemampuan pemecahan masalah matematika secara keseluruhan yaitu sebesar 68,75. Rata-rata kemampuan pemecahan masalah siswa yang memiliki motivasi tinggi yaitu 75.6, Siswa dengan motivasi sedang rata-rata kemampuan pemecahan masalah matematika 70.7, dan rata-rata kemampuan pemecahan masalah untuk siswa dengan motivasi rendah yaitu 59,4. Hasil analisis dengan uji anova dua jalur bahwa terdapat perbedaan kemampuan pemecahan masalah matematika siswa antara motivasi belajar tinggi, sedang, dan rendah.
\end{abstract}

Kata kunci: Kemampuan Pemecahan Masalah, Motivasi Belajar Matematika

\begin{abstract}
This study aims to describe the ability of problem solving in terms of students' motivation to learn mathematics. This research is a quantitative descriptive research. The subject of this research is statistics. The subjects in this study were students of class XII IPS 1 SMA 17 Pandeglang in the 2019/2020 school year, totaling 32 students. Data collection instruments used included final test questions to see students' problem solving abilities and student learning motivation questionnaire sheets. Data analysis techniques in this study used a percentage score and two-way ANOVA. problem solving skills and students' motivation to learn mathematics viewed from the high, medium, and low categories. Based on the results of data processing, that the distribution of high motivation to learn $25 \%$ of students, learning motivation is $47 \%$ of students, and low motivation of $28 \%$ of students. With an ideal score of 100, obtained an average overall mathematical problem solving ability that is equal to 68.75. The average problem solving ability of students who have high motivation is 75.6, Students with moderate motivation average mathematical problem solving ability is 70.7 , and the average problem solving ability for students with low motivation is 59.4. The results of the analysis with the two-way ANOVA test show that there are differences in students' mathematical problem solving abilities between high, medium and low learning motivation.
\end{abstract}

Keywords: Problem Solving skills, Mathematics Learning Motivation

\section{PENDAHULUAN}

Ilmu pengetahuan dan teknologi saat ini berkembang sangat pesat melalui proses Pendidikan di sekolah. Matematika sebagai salah satu mata pelajaran yang ada dalam kurikulum di Indonesia, dapat digunakan sebagai sarana untuk menciptakan sumber daya manusia yang berkualitas dan berdaya saing yang tinggi. Matematika sebagai sarana untuk menyongsong era globalisasi dan revolusi industri 4.0. 
Dalam kemajuan perkembangan ilmu matematika sering memulai suatu penerapan yang baru pada berbagai bidang dalam kehidupan manusia. Akan tetapi dalam kenyataannya masih banyak siswa yang belum merasakan manfaat dari matematika dan masih dianggap sebagai mata pelajaran yang sulit, hal tersebut dikemukakan oleh (Setyaningsih \& Abadi, 2018).

Pendidikan sebagai ujung tombak kemajuan bangsa, terutama dalam menghadapi era globalisasi di mana kemajuan teknologi yang pesat menyebabkan perubahan struktur kehidupan dalam masyarakat. Kemajuan tersebut pendidik dituntut untuk berperan aktif dalam menjalankan misi pendidikan. Berbagai perubahan kurikulum yang dilakukan oleh pemerintah sejak tahun 1975 hingga tahun 2004 yang disempurnakan dengan Kurikulum Tingkat Satuan Pendidikan (KTSP) dan yang terbaru adalah kurikulum 2013 atau yang biasa disebut K13 bertujuan untuk meningkatkan kualitas pendidikan. Akibat adanya perubahan kurikulum ini tidak hanya sekedar menyempurnakan kurikulum sebelumnya tetapi merupakan suatu perombakan baru dalam paradigma pendidikan. Paradigma ini pada prinsipnya menekankan adanya pendidikan yang bermakna bagi peserta didik. Oleh karena itu guru sebagai pendidik sangat berperan dalam menentukan proses pembelajaran sehingga pembelajaran yang dilakukan dapat melibatkan kreativitas siswa dalam memahami dan memaknai konsep setiap topik pembelajaran yang dipelajari.

Meskipun guru sekarang berperan menjadi fasilitator akan tetapi guru merupakan objek dalam pembelajaran di kelas, sehingga siswa harus berperan aktif dalam pembelajaran, agar kegiatan di dalam kelas menjadi menarik, semua siswa harus berperan dengan memperhatikan arahan dai guru. Diperlukan guru yang mampu memberikan keteladanan, membangun kemauan, dan mengembangkan potensi dan kreativitas siswa. Sehingga siswa bersemangat dalam belajarnya.

Pada umumnya model pembelajaran yang dilaksanakan adalah guru cenderung lebih mendominasi pembelajaran atau teacher centered (berpusat pada guru) sehingga siswa kurang aktif dalam proses belajar mengajar. Hal ini tentunya akan berdampak pada pencapaian hasil belajar siswa. Pembelajaran yang hanya berpusat kepada guru sampai saat ini masih terlaksana di sekolah-sekolah, seolah-olah guru yang mendominasi proses belajar mengajar sehingga kesempatan siswa untuk belajar aktif sangat terbatas (Mukti, Wandira, Y, \& Pamungkas, 2017).

Berkaitan dengan pemecahan masalah matematis, dalam lampiran Peraturan Menteri No. 22 tahun 2006 tentang Standar Isi yang menjelaskan bahwa pelajaran matematika di sekolah menengah bertujuan untuk: (1) memahami konsep matematika, menjelaskan 
keterkaitan antar konsep dan mengaplikasikan konsep atau algoritma secara luwes, akurat, efisien, dan tepat dalam pemecahan masalah. (2) menggunakan penalar-an pada pola dan sifat, melakukan manipulasi matematika dalam membuat generalisasi, menyusun bukti, atau menjelaskan gagasan dan pernyataan matematika. (3) memecahkan masa-lah yang meliputi kemampuan memahami masalah, merancang model matematika, menye-lesaikan model dan menafsirkan solusi yang diperoleh. (4) mengkomunikasikan gagasan dengan simbol, tabel, diagram, atau media lain untuk memperjelas keadaan atau masalah. (5) memiliki sikap menghargai kegunaan mate-matika dalam kehidupan, yaitu memiliki rasa ingin tahu, perhatian dan minat dalam mempelajari matematika, serta sikap ulet dan percaya diri dalam pemecahan masalah (Angkotasan, 2013).

Indikator kemampuan pemecahan masalah yaitu mengidentifikasi unsur-unsur yang diketahui, ditanyakan, dan kecukupan unsur yang diperlukan, merumuskan masalah matematis atau menyusun model matematis, menerapkan strategi untuk menyelesaikan masalah, serta menjelaskan atau menginterpretasikan hasil penyelesaian masalah (Lestari, 2015).

Motivasi belajar adalah suatu daya, dorongan atau kekuatan, baik yang datang dari diri sendiri maupun dari luar yang mendorong peserta didik untuk belajar. Adapun indikator dari motivasi belajar yaitu adanya dorongan dan kebutuhan belajar, menunjukkan perhatian dan minat terhadap tugas-tugas yang diberikan, tekun menghadapi tugas, ulet menghadapi kesulitan, dan adanya hasrat dan keinginan berhasil. Indikator tersebut dipaparkan menurut (Lestari, 2015).

Akan tetapi sangat disayangkan bahwa pada proses pembelajaran di sekolah seringkali ditemukan siswa yang berhadapan dengan berbagai permasalahan yang menghambat proses pengembangan dirinya. Hal tersebut ditandai dengan munculnya perasaan mudah putus asa dalam menyelesaikan soal matematika, kurang konsentrasi, kurang bersemangat dalam mengikuti pembelajaran, tidak berupaya untuk me-nyelesaikan tugas dengan baik, tidak percaya diri saat diminta untuk mengerjakan soal di depan kelas, serta memiliki perasaan takut salah dan tegang saat menjawab pertanyaan dari guru. Kondisi-kondisi tersebut berpengaruh terhadap pencapaian hasil belajar (Rahayu \& Hartono, 2016).

Oleh sebab itu siswa terkadang memiliki motivasi yang kurang baik dalam mengikuti pelajaran tersebut, karena merasa minder apabila sudah mendapatkan nilai di bawah rata-rata dalam mata pelajaran matematika. Siswa merasa kurang peraya diri dalam mengikuti pelajaran matematika dalam kelas. 
Motivasi belajar dapat timbul karena faktor intrinsik berupa hasrat dan keinginan berhasil serta dorongan kebutuhan belajar dan harapan akan cita-cita. Sedangkan faktor ekstrinsiknya adalah adanya penghargaan, lingkungan belajar yang kondusif, dan kegiatan belajar yang menarik. Tetapi harus diingat, kedua faktor tersebut disebabkan oleh rangsangan tertentu, sehinggga siswa berkeinginan untuk melakukan aktivitas belajar yang lebih giat dan semangat. Oleh karena itu sangantlah tepat apabila guru menggunakan berbagai macam metode dan pendekatan pembelajaran agar pembelajaran tidak monoton dan membosankan sehingga merangsang siswa untuk belajar dan merasa senang datang ke sekolah (Khamid \& Santosa, 2016).

Kemampuan motivasi sebagai salah satu aspek penunjang perkembangan intelektual peserta didik yang penting untuk diperhatikan dalam proses belajar mengajar di dalam kelas. Menurut penelitian peserta didik yang memiliki motivasi tinggi maka perkembangan intelektualnya akan cepat berkembang (Fadillah \& Baist, 2017).

Amri \& Abadi, (2013) menyatakan bahwa belum maksimalnya peserta didik dalam kemampuan pemecahan masalah matematika tidak hanya disebabkan oleh sifat matematika yang abstrak tersebut tetapi juga tidak terlepas dari proses pembelajaran matematika yang ada dalam setiap kelasnya selama ini yaitu guru hanya menerangkan materi, memberi contoh soal dan memberikan latihan soal. Oleh karena itu perlu diciptakan kondisi pembelajaran matematika yang menyenangkan dan memotivasi bagi peserta didik. Sehingga kemampuan pemecahan masalah sanagat berhubungan erat dengan motivasi siswa.

Kemampuan pemecahan masalah mendapat perhatian yang serius dalam pembelajaran matematika. Kemampuan pemecahan masalah menjadi fokus dalam pembelajaran matematika, karena kemampuan tersebut bisa digunakan siswa tidak hanya untuk memecahkan masalah matematika tapi juga bisa digunakan dalam pelajaran lain, dan yang terpenting bisa digunakan dalam kehidupan sehari-hari (Wahidin \& Sugiman, 2014).

Motivasi dijelaskan bahwa keadaan kondisi emosi siswa dapat terjadi naik turun dalam diri siswa. Emosi dan motivasi sangat penting dalam pembelajaran di awal pengembangan pendidikan matematika (Schukajlow \& Pekrun, 2017).

Polya mengemukakan bahwa langkah-langkah pemecahan masalah matematika terdiri dari 4 langkah (Novitasari \& Wilujeng, 2018), yaitu:

1. Memahami masalah (understand the problem)

2. Merencanakan pemecahannya (devising a plan)

3. Menyelesaikan masalah sesuai rencana (carry out a plan)

Prima, Vol. 4, No. 1, Januari 2020, 1-10. 
4. Melakukan pengecekan kembali terhadap semua langkah yang telah dikerjakan.

Langkah ini merupakan langkah akhir untuk memastikan hasil yang paling tepat. Selama berlangsungnya langkah ini solusi masalah harus dipertimbangkan dengan pengecekan ulang perhitungannya. Kegiatan yang dapat dilakukan pada langkah ini adalah menganalisis dan mengevaluasi apakah prosedur yang diterapkan dan hasil yang diperoleh benar, atau apakah prosedur dapat dibuat generalisasinya. Untuk dapat melakukan tahap ini dengan baik, maka perlu latihan mengenai:

a. Memeriksa penyelesaian jawaban.

b. Memeriksa apakah jawaban yang diperoleh masuk akal.

c. Memeriksa pekerjaan, adakah perhitungan atau analisis yang salah.

d. Memeriksa pekerjaan, adakah yang kurang lengkap atau kurang jelas.

Maka dari itu, seorang guru harus mampu memilih model pembelajaran dalam menyampaikan materi pelajaran agar diperoleh hasil belajar yang maksimal bagi siswa khususnya pelajaran matematika. Hal tersebut merupakan upaya dalam rangka meningkatkan mutu Pendidikan (Nia \& Effendi, 2018).

Pemecahan masalah dapat diinterprestasikan dalam tiga kategori yang berbeda. Pertama, pemecahan masalah sebagai tujuan. Kategori ini memfokuskan belajar bagaimana cara memecahkan masalah. Dalam hal ini, pemecahan masalah terbebas dari prosedur atau metode dan konten matematika itu sendiri. Kedua, pemecahan masalah sebagai proses. Kategori ini terfokus pada metode, prosedur, strategi, serta heuristic yang digunakan dalam pemecahan masalah. Ketiga, pemecahan masalah sebagai keterampilan dasar yang salah satunya menyangkut keterampilan minimal yang dimiliki siswa dalam menguasi matematika. (Mukti et al., 2017)

Berdasarkan kajian dan uraian di atas dapat disimpulkan bahwa kemampuan pemecahan masalah siswa dapat meningkatkan motivasi belajar matematika siswa.

\section{METODE PENELITIAN}

Jenis penelitian ini adalah penelitian deskriptif kuantitatif. Subjek penelitian ditentukan melalui purpose sampling dan penelitian ini dilakukan di kelas XII IPS 1 SMAN 17 Pandeglang dengan subjek berjumlah 32. Teknik pengumpulan data pada penelitian menggunakan metode tes, dan pengisian angket pada subjek penelitian. Soal tes terdiri dari 5 soal tes kemampuan pemevahan masalah. Motivasi belajar matematika berdasarkan kategori tinggi, sedang, dan rendah. Data hasil tes tertulis, dianalisis berdasarkan indikator-indikator yang memenuhi proses berfikir pemecahan masalah. 
Teknik pengumpulan data pada penelitian ini, terdapat dua jenis. Adapun kedua jenis tersebut yaitu: Pertama, tes kemampuan pemecahan masalah indicator keterukurannya yakni melalui kemampuan siswa dalam menyelesaikan tes uraian matematis yang meliputi pemahaman masalah, merencanakan penyelesaian soal, melaksanakan rencana penyelesaian, dan melihat kembali hasil dan proses. Kedua, pengisian angket yang terdiri dari 40 pernyataan terkait motivasi belajar matematika. Skala yang di gunakan dalam soal tes yaitu skala 100,00 .

Tabel 1. Teknik Pengumpulan Data

\begin{tabular}{lccc}
\hline \multicolumn{1}{c}{ Data } & $\begin{array}{c}\text { Teknik Pengumpulan } \\
\text { Data }\end{array}$ & Instrumen & Sumber data \\
\hline $\begin{array}{l}\text { Motivasi Belajar } \\
\text { Matematika }\end{array}$ & Pengisian Angket & $\begin{array}{c}\text { Angket }(40 \text { butir } \\
\text { Pernyataan })\end{array}$ & Siswa \\
$\begin{array}{l}\text { Kemampuan Pemecahan } \\
\text { Masalah }\end{array}$ & Tes & $\begin{array}{c}\text { Lembar Tes Tulis (5 item } \\
\text { soal) }\end{array}$ & Siswa \\
\hline
\end{tabular}

Acuan dalam pengelompokkan rata-rata kemampuan pemecahan masalah siswa dengan kriteria pada skala 100 dengan interpretasi sebagai berikut:

Tabel 2. Acuan rata-rata tes kemampuan pemecahan masalah

\begin{tabular}{cc}
\hline Rata-rata & Interpretasi \\
\hline $0,00-50,00$ & Rendah \\
$51,00-75,00$ & Sedang \\
$76,00-100,00$ & Tinggi \\
\hline
\end{tabular}

Acuan dalam menentukan skor angket dengan menggunakan persentase skor rata-rata angket yang diperoleh siswa dengan interpretasi sebagai berikut:

Tabel 3. Acuan Rata-rata Skor Angket Motivasi Belajar Siswa

\begin{tabular}{cc}
\hline Rata-rata & Interpretasi \\
\hline $0 \%-50 \%$ & Rendah \\
$51 \%-75 \%$ & Sedang \\
$76 \%-100 \%$ & Tinggi \\
\hline
\end{tabular}

Teknik analisis data yang digunakan untuk mengetahui kemampuan pemecahan masalah siswa dan motivasi belajar matematika adalah analisis statistik deskriptif. Sementara untuk mengetahui ada atau tidaknya perbedaan rata-rata kemampuan pemecahan masalah ditinjau dari perbedaan motivasi belajar dengan menggunakan satistik inferensial yaitu analisis statistik anova.

\section{HASIL DAN PEMBAHASAN}

Motivasi belajar matematika dapat diketahui dari hasil pengisian angket yang disebarkan pada siswa, hasil pengisian angket tersebut dapat membedakan motivasi belajar 
siswa yang terdiri dari motivasi tinggi, motivasi sedang, dan motivasi rendah. Ketiga kategori motivasi tersebut dapat terukur dari dimensi gaya belajar siswa yang meliputi adanya dorongan dan kebutuhan belajar, menunjukkan perhatian dan minat terhadap tugas-tugas yang diberikan, tekun menghadapi tugas, ulet menghadapi kesulitan, dan adanya hasrat dan keinginan berhasil. Adapun setelah melakukan pengumpulan data penelitian dengan membagikan instrumen angket pada siswa, diperoleh pengelompokkan motivasi belajar sebagai berikut:

Tabel 4. Sebaran Motivasi Belajar Siswa SMAN 17 Pandeglang

\begin{tabular}{ccc}
\hline Motivasi Belajar & Frekuensi & Persentase \\
\hline Tinggi & 8 & $25 \%$ \\
Sedang & 15 & $47 \%$ \\
Rendah & 9 & $28 \%$ \\
\hline Jumlah & 32 & $100 \%$ \\
\hline
\end{tabular}

Berdasarkan Tabel 4 diperoleh bahwa motivasi belajar matematika siswa yang dimiliki siswa kelas XII IPS1 SMAN 17 Pandeglang dengan jumlah 32 siswa yaitu kategori motivasi tinggi sebanyak 8 siswa dengan persentase sebesar $25 \%$, kategori motivasi sedang sebanyak 15 siswa dengan persentase $47 \%$, dan kategori motivasi rendah sebanyak 9 siswa dengan persentase $28 \%$.

Kemampuan pemecahan masalah siswa terukur melalui kemampuan dalam memahami masalah yang terdapat dalam soal, dapat merencanakan pemecahan masalah dalam soal, menyelesaikan masalah sesuai rencana, dan melakukan pengecekan kembali terhadap semua langkah yang telah dikerjakan. Adapun data hasil penelitian descriptive statistics kemampuan pemecahan masalah siswa diperoleh dari hasil tes uraian sebanyak 5 item soal pada materi statistika yang disebarkan pada siswa kelas XII IPS1 SMAN 17 Pandeglang sebanyak 32 siswa seperti yang ditampilkan pada Tabel 5 berikut.

Tabel 5. Data Deskriptif Hasil Tes Kemampuan Pemecahan Masalah

\begin{tabular}{cccccc}
\hline Motivasi Belajar & N & Mean & Std Deviation & Minimum & Maksimum \\
\hline Tinggi & 8 & 75,63 & 10,84 & 65 & 90 \\
Sedang & 15 & 70,67 & 6,02 & 65 & 85 \\
Rendah & 9 & 59,44 & 2,35 & 50 & 85 \\
\hline Jumlah & 32 & 68,75 & 10,61 & 50 & 90 \\
\hline
\end{tabular}

Dapat diketahui bahwa total sampel penelitian sebanyak 32 siswa kelas XII IPS 1 di SMAN 17 Pandeglang diperoleh nilai rata-rata kemampuan pemecahan masalah siswa dengan motivasi tinggi yaitu 75,63, standar deviasi 10,84, nilai minimum sebesar 65 , dan nilai maksimum sebesar 90. Kategori motivasi sedang memperoleh nilai rata-rata 70,67, 
standar deviasi 6,02, nilai minimum sebesar 65, dan nilai maksimum sebesar 85 . Kategori motivasi rendah memperoleh nilai rata-rata 59,44, standar deviasi 2,35, nilai minimum 50 dan nilai maksimum 85 .

Setelah data diketahui berdistribusi normal dan memiliki varian yang sama (homogen), selanjutnya dilakukan uji Anova. Uji Anova dilakukan untuk mengetahui ada atau tidaknya perbedaan kemampuan pemecahan masalah matematika siswa ditinjau dari motivasi belajar siswa.

Tabel 6. Hasil Uji One Way Anova

\begin{tabular}{ccccc}
\hline & $\begin{array}{c}\text { Sum of } \\
\text { Squares }\end{array}$ & Df & Mean square & F \\
\hline Between Groups & 26284,52 & 1 & 26284,52 & 76,178 \\
Within Groups & 21392,47 & 62 & 345,0398 & \\
\hline Total & 47676,98 & 63 & & \\
\hline
\end{tabular}

Berdasarkan Tabel 6, diperoleh nilai $F_{\text {hitung }}>F_{\text {tabel }}$, maka tolak $H_{0}$ artinya ada perbedaan nilai rata-rata kemampuan pemecahan masalah siswa yang antara motivasi belajar tinggi, sedang, dan rendah. Berdasarkan sebaran data tersebut, sebagian besar siswa memiliki motivasi sedang.

Aktivitas kelompok beserta tanggapan siswa menjadi dua hal yang juga akan diamati, sebagai data tambahan dalam melihat perkembangan kemampuan pemecahan masalah. Aktivitas yang berkaitan dengan kemampuan siswa dalam memecahkan masalah diamati melalui lembar observasi aktivitas kelompok. Tanggapan siswa yang tertuang dalam jurnal harian siswa dianalisis sebagai data untuk mengetahui perkembangan dan respon yang dialami siswa dalam memecahkan masalah (Firmansyah, 2017).

Hasil Penelitian lebih lanjut menemukan bahwa pada siswa bermotivasi belajar tinggi skor angket diperoleh rerata skor tes kemampuan pemecahan masalah matematika untuk siswa yang memiliki motivasi belajar tinggi. Pada umunya siswa yang berkemampuan sedang memiliki motivasi sedang dan yang memiliki kemampuan pemecahan masalah rendah memiliki skor angket yang rendah.

\section{SIMPULAN DAN SARAN}

Berdasarkan hasil penelitian dapat disimpulkan sebagai berikut:

a. Kemampuan Pemecahan Masalah Siswa yang memiliki motivasi tinggi

Berdasarkan hasil penelitian yang dilakukan. Rata-rata kemampuan pemecahan masalah yang memiliki motivasi tinggi yaitu 75,63 dengan persentase jumlah siswa $25 \%$.

b. Kemampuan Pemecahan Masalah Siswa yang memiliki motivasi sedang

Prima, Vol. 4, No. 1, Januari 2020, 1-10. 
Berdasarkan hasil penelitian yang dilakukan. Rata-rata kemampuan pemecahan masalah yang memiliki motivasi rendah yaitu 70,67 dengan persentase jumlah siswa $47 \%$.

c. Kemampuan Pemecahan Masalah Siswa yang memiliki motivasi rendah Berdasarkan hasil penelitian yang dilakukan. Rata-rata kemampuan pemecahan masalah yang memiliki motivasi rendah yaitu 59,44 dengan persentase jumlah siswa $28 \%$.

d. Berdasarakan hasil uji anava dua jalur terdapat perbedaan antara kemampuan pemecahan masalah siswa berdasarkan perbedaan motivasi belajar tinggi, sedang dan rendah.

\section{DAFTAR PUSTAKA}

Amri, M. S., \& Abadi, A. M. (2013). Pengaruh PMR dengan TGT terhadap Motivasi, Sikap, dan Kemampuan Pemecahan Masalah Geometri Kelas VII SMP. Pythagoras: Jurnal Pendidikan Matematika, 8(1), 55-68. Retrieved from https://journal.uny.ac.id/index.php/pythagoras/article/view/8494/7007.

Angkotasan, N. (2013). PBL and TAI Type Cooperative Learning Model in Terms of Reflective Thinking and Mathematic Problem Solving Abilities. PYTHAGORAS: Jurnal Pendidikan Matematika, 8(1), 92-100. Retrieved from http://journal.uny.ac.id/index.php/pythagoras/article/view/8497/7010.

Fadillah, A., \& Baist, A. (2017). Hubungan motivasi dan perilaku terhadap hasil belajar mata kuliah matematika ekonomi 1 1,2, 1(1), 43-48.

Firmansyah, M. A. (2017). Upaya Meningkatkan Kemampuan Pemecahan Masalah Matematik melalui Model Learning Cycle dalam Pembelajaran Matematika, 6(1).

Khamid, A., \& Santosa, R. H. (2016). Keefektifan pendekatan PBL dan CTL ditinjau dari komunikasi matematis dan motivasi belajar siswa SMP. PYTHAGORAS: Jurnal Pendidikan Matematika, 11(2), 111. https://doi.org/10.21831/pg.v11i2.10660

Mukti, S., Wandira, A., Y, I. A. V, \& Pamungkas, A. S. (2017). Efektivitas Model Pembelajaran Kooperatif Tipe Think Pair Share Dan The Power Of Two Ditinjau dari Kemampuan Pemecahan Masalah Matematis, 1(1).

Nia, K., \& Effendi, S. (2018). Penerapan Pembelajaran Advance Organizer dalam Peningkatan Kemampuan Pemahaman Matematis dan Motivasi Belajar Siswa SMK, 2(1), 33-48.

Novitasari, N., \& Wilujeng, H. (2018). Analisis Kemampuan Pemecahan Masalah Matematika Siswa Smp Negeri 10 Tangerang. Prima: Jurnal Pendidikan Matematika, 2(2), 137-147. https://doi.org/10.31000/PRIMA.V2I2.461 
Rahayu, E., \& Hartono, H. (2016). Keefektifan Model PBL dan PjBL Ditinjau dari Prestasi, Kemampuan Berpikir Kritis, dan Motivasi Belajar Matematika Siswa SMP. PYTHAGORAS: Jurnal Pendidikan Matematika, $11(1), \quad 1$. https://doi.org/10.21831/pg.v11i1.9629

Schukajlow, S., \& Pekrun, K. R. R. (2017). Emotions and motivation in mathematics education: theoretical considerations and empirical contributions. ZDM, 49(3), 307322. https://doi.org/10.1007/s11858-017-0864-6.

Setyaningsih, T. D., \& Abadi, A. M. (2018). Keefektifan PBL seting kolaboratif ditinjau dari prestasi belajar aljabar, kemampuan berpikir kritis, dan kecemasan siswa The effectiveness of PBL with collaborative setting in terms of algebraic achievement, critical thinking ability, and math anxiet, 5(2), 190-200.

Wahidin, W., \& Sugiman, S. (2014). Pengaruh pendekatan PMRI terhadap motivasi berprestasi, kemampuan pemecahan masalah, dan prestasi belajar. PYTHAGORAS: Jurnal Pendidikan Matematika, 9(1), 99-109. https://doi.org/10.21831/PG.V9I1.9072 